\title{
Global gene expression in Escherichia coli, isolated from the diseased ocular surface of the human eye with a potential to form biofilm
}

Konduri Ranjith 1,3, Kotakonda Arunasri', Gundlapally Sathyanarayana Reddy ${ }^{2}$, HariKrishna Adicherla², Savitri Sharma ${ }^{1}$ and Sisinthy Shivaji $1^{*}$

\begin{abstract}
Background: Escherichia coli, the gastrointestinal commensal, is also known to cause ocular infections such as conjunctivitis, keratitis and endophthalmitis. These infections are normally resolved by topical application of an appropriate antibiotic. But, at times these E. coli are resistant to the antibiotic and this could be due to formation of a biofilm. In this study ocular E. coli from patients with conjunctivitis, keratitis or endophthalmitis were screened for their antibiotic susceptibility and biofilm formation potential. In addition DNA-microarray analysis was done to identify genes that are involved in biofilm formation and antibiotic resistance.

Results: Out of 12 ocular E. coli isolated from patients ten isolates were resistant to one or more of the nine antibiotics tested and majority of the isolates were positive for biofilm formation. In E. coli L-1216/2010, the best biofilm forming isolate, biofilm formation was confirmed by scanning electron microscopy. Confocal laser scanning microscopic studies indicated that the thickness of the biofilm increased up to $72 \mathrm{~h}$ of growth. Further, in the biofilm phase, E. coli L-1216/2010 was 100 times more resistant to the eight antibiotics tested compared to planktonic phase. DNA microarray analysis indicated that in biofilm forming E. coli L-1216/2010 genes encoding biofilm formation such as cell adhesion genes, LPS production genes, genes required for biofilm architecture and extracellular matrix remodeling and genes encoding for proteins that are integral to the cell membrane and those that influence antigen presentation are up regulated during biofilm formation. In addition genes that confer antimicrobial resistance such as genes encoding antimicrobial efflux ( $m d t \mathrm{M}$ and $c y c \mathrm{~A}$ ), virulence (ins $\mathrm{Q}$, yjgK), toxin production (sat, yjgK, chpS, chpB and ygjN), transport of amino-acids and other metabolites ( $c b r \mathrm{~B}, \mathrm{cbrC}$, hisl and $\mathrm{mg} / \mathrm{B}$ ) are also up regulated. These genes could serve as potential targets for developing strategies for hacking biofilms and overcoming antibiotic resistance.

Conclusions: This is the first study on global gene expression in antibiotic resistant ocular E. coli with a potential to form biofilm. Using native ocular isolates for antibiotic susceptibility testing, for biofilm formation and global gene expression is relevant and more acceptable than using type strains or non clinical strains which do not necessarily mimic the native isolate.
\end{abstract}

Keywords: Ocular E. coli, Biofilm, Antibiotic susceptibility, DNA microarray, Differential expression of genes

\footnotetext{
*Correspondence: shivas@lvpei.org

1 Jhaveri Microbiology Centre, Brien Holden Eye Research Centre, LV

Prasad Eye Institute, Kallam Anji Reddy campus, Hyderabad 500007, India

Full list of author information is available at the end of the article
} 


\section{Background}

Escherichia coli, is a coliform bacterium that occurs as a commensal in the gut of humans and other warm blooded mammals [1] and exhibits high degree of genotypic and phenotypic diversity. A few of them are pathogenic $[2,3]$ and include the verotoxigenic (VTEC), entero-haemorrhagic (EHEC, a subclass of the VTEC class), entero-invasive (EIEC) and uro-pathogenic/extra-intestinal pathogenic (UPEC/ExPEC) classes and are harmful to their hosts [3, 4]. E. coli also inhabits different environmental niches viz., soil, water, sediment, food, abiotic and biotic surfaces [5] like the surface of the eye and the inner surface of the eye lids. But, E. coli is not the only bacterium on the ocular surface and includes several other Gram-negative bacteria (Neisseria spp., Pseudomonas aeruginosa and Haemophilus influenzae) [6, 7], Gram-positive bacteria (Staphylococcus epidermidis, S. aureus, Corynebacterium spp., Streptococci spp., and Propionibacterium acnes), fungi (Fusarium solani, Cladosporium sphaerospermum, Acremonium implicatum, Candida albicans and Aspergillus fumigatus) [8-10] and viruses. More recently using non-cultivable molecular techniques based on 16S rRNA gene sequencing a greater bacterial diversity has been observed associated with the eye [11-14]. In all these studies the diversity of bacteria was very different and genera Staphylococcus, Corynebacterium, Propionibacterium and Streptococcus were the only common genera. Thus based on these studies it is difficult to conclude as to what constitutes the ocular surface microbiota (or a core microbiome) or whether the microbiota are only transiently present [15].

Characterising the ocular microbiome is important because following trauma or under immuno-compromised conditions these ocular microbiota may cause infection of the eye (such as keratitis, endophthalmitis, orbital cellulitis etc.) often leading to loss of vision. But, ocular infections such as conjunctivitits and keratitis may also originate from dirty fingers and contaminated contact lenses. Normally the infection is resolved following treatment with antifungal/antibacterial agents. However, over the years many of these organisms have become resistant to drugs. In preliminary studies carried out at the Jhaveri microbiology centre at L V Prasad Eye Institute (a tertiary eye care center), Hyderabad, India, several corneal pathogens were observed to be tolerant to one or more ocular antibiotics thus implying the emergence of tolerant strains [16]. Resistance to drugs may be linked to biofilm formation. Bacteria in a biofilm exhibit increased resistance to antibiotics due to binding of the antibiotics to the extracellular polymeric substances (EPS), due to production of enzymes that inactivate antibiotics, due to nutrient and oxygen limitation, due to increase in the efficiency of efflux pumps and due to up regulation of drug resistance-associated genes $[17,18]$.
Bacteria have been reported to form biofilm on contact lenses, intraocular lenses, lid implants, orbit implants, socket implants, scleral buckles and suture material [19, 20]. P. aeruginosa, S. epidermidis, Streptococcus spp. and Enterobacter have been identified to be a part of the biofilm [18]. Katiyar et al. [21] demonstrated that $85 \%$ of the isolates from intraocular lenses represented by $P$. aeruginosa, Staphylococcus aureus, S. epidermidis, Micrococcus luteus, S. marcescens, Neisseria spp., Moraxella spp., Bacillus spp., E. coli, Proteus mirabilis, Enterobacter agglomerans and Klebsiella spp., exhibited the potential to form biofilms and were resistant to antibiotics.

Information on genes that are differentially regulated during biofilm formation and correlating the results to increased resistance to antimicrobials have not been studied in ocular bacteria. With this in view, in the present study ocular isolates of $E$. coli which are known to cause about $1.1 \%$ of the total ocular infections [22] such as keratitis [23], endophthalmitis [24, 25], conjunctivitis [6], pan-ophthalmitis [26] and eyelid abscess [27], were used as model systems to investigate antibiotic susceptibility and biofilm formation potential. In addition global gene expression was studied by DNA-microarray analysis to identify genes that are involved in biofilm formation and antibiotic resistance. This approach using the native ocular isolates for global gene expression is relevant considering that studies have indicated that use of type strains (or non clinical strains) may not be the right approach to understand antibiotic resistance in a biofilm forming microorganism [28, 29]. Since the type strains of the same species need not necessarily mimic exactly the native isolate. The results of this study would unravel the identity of genes that are differentially regulated during biofilm formation and identify differentially regulated genes related to increased resistance to antimicrobials.

\section{Methods \\ Collection of samples and bacterial identification}

The Jhaveri Microbiology Centre of the Prof. Brien Holden Eye Research Centre at the L V Prasad Eye Institute, Hyderabad, India receives over 4000 clinical samples per annum from patients with eye infections. These samples are processed for the detection of bacteria and fungi and subsequently the cultures are purified, identified and preserved in tryptone soya broth with $30 \%$ glycerol at $-80{ }^{\circ} \mathrm{C}$. This study used $12 \mathrm{E}$. coli isolates preserved between 2010 and 2014. All preserved isolates of bacteria were cultured on $5 \%$ sheep blood agar medium at $37^{\circ} \mathrm{C}$. A pure homogenous culture obtained after repeated streaking was then subjected to Vitek 2 compact (bioMérieux, France) analysis for identification of the bacterium. Tests were performed according to the manufacturer's 
instructions and the cultures were identified with the database of the instrument.

\section{Biofilm detection}

The potential to form a biofilm was assessed in 12 ocular isolates of $E$. coli using the microtiter/tissue culture plate (TCP) method [30]. In the TCP or crystal violet method a single colony of the bacterium was inoculated into $5 \mathrm{ml}$ medium of brain-heart infusion (BHI) and tryptic soy broth (TSB) (HiMedia Laboratories, Secunderabad, India) separately and incubated overnight. The culture was then adjusted to 0.5 McFarland units, diluted 100fold and $100 \mu \mathrm{l}$ of the diluted inoculum was dispensed into a single well of a 96 well plate (Thermo Fisher Scientific, Nunclon $^{\mathrm{TM}}$, Denmark) containing $100 \mu \mathrm{l}$ of fresh medium. The plate was then incubated at $37^{\circ} \mathrm{C}$ for $72 \mathrm{~h}$. The broth was then discarded by inverting the plate and gently tapping it after which it was washed thrice with $200 \mu$ lof phosphate buffered saline (PBS, SigmaAldrich Corporation, St. Louis, MO, USA) and allowed to dry for $30 \mathrm{~min}$. The bacteria in the biofilm adhering to the plate were then stained with $200 \mu \mathrm{l}$ of $0.1 \%$ Crystal violet for $30 \mathrm{~min}$ and the Crystal violet associated with the cells was then extracted with $200 \mu \mathrm{l}$ of ethanol and quantified spectrophotometrically at $595 \mathrm{~nm}$ [30]. Visually, wells without the inoculum (control) and wells with bacteria that did not possess the potential to form biofilm were white to pale blue in colour. But, wells inoculated with bacteria which have a potential to form a biofilm are moderate to dark blue in colour indicative of biofilm formation. Wells without cells inoculated served as the control and the OD was $<0.1$ at $595 \mathrm{~nm}$ and was deducted from the biofilm positive strains (OD >0.3 at $595 \mathrm{~nm}$ ) and the biofilm negative strains (OD $<0.3$ at $595 \mathrm{~nm}$ ).

The TCP method was used to ascertain the optimum temperature and $\mathrm{pH}$ required for biofilm formation using two different media. The 12 ocular $E$. coli isolates were either incubated at 30 or $37^{\circ} \mathrm{C}$ in $\mathrm{BHI}$ or TSB and the $\mathrm{pH}$ of the medium was adjusted to 5, 6, 7, 8 or 9 and incubated for $72 \mathrm{~h}$. Following crystal violet staining the biofilm was quantified as above by recording the absorbance at $595 \mathrm{~nm}$.

\section{Visualization of biofilm by scanning-electron microscopy (SEM) and confocal laser scanning microscope (CLSM)} A single colony of E. coli L-1216/2010 was incubated overnight at $37^{\circ} \mathrm{C}$ in $\mathrm{BHI}$ or TSB. The culture was then adjusted to $3 \mathrm{McFarland}$ with the medium and then $20 \mu \mathrm{l}$ of $3 \mathrm{McF}$ arland culture was made up to $200 \mu \mathrm{l}$ using the same medium and transferred on to a sterile glass cover slip $(10 \times 10 \mathrm{~mm})$ and placed in the 12 well plate (Thermo Fisher Scientific, Nunclon ${ }^{\mathrm{TM}}$, Denmark) and incubated for different time intervals $(24,48$ and $72 \mathrm{~h}$.) at $37^{\circ} \mathrm{C}$. After incubation, the adhering biofilm was washed, fixed with $2.5 \%$ glutaraldehyde solution for $2 \mathrm{~h}$, washed thrice with distilled water and dehydrated through a graded series of ethanol $(10,25,50,70,90$, and $100 \%)$ for $20 \mathrm{~min}$ in each grade. Finally, the biofilms were air dried at $37 \pm 1{ }^{\circ} \mathrm{C}$ for $24 \mathrm{~h}$. Prior to visualisation of the biofilm using a SEM (HITACHI-Model S-3400N, Japan) the biofilms were metalized by gold sputtering for $45 \mathrm{~s}$ in a High Vacuum Evaporator (SC7620 PALARON Sputter Coater).

Escherichia coli biofilms of strain L-1216/2010 were also visualized by CLSM. The biofilms were grown for 24,48 and $72 \mathrm{~h}$ as above, washed twice gently with autoclaved water and the adhering biofilm fixed with $4 \%$ formaldehyde (Himedia-Secunderabad, India) for $45 \mathrm{~min}$. The fixed biofilms were then washed twice with autoclaved water and stained with $200 \mu \mathrm{l}$ of $1.67 \mu \mathrm{M}$ Syto ${ }^{\circledR} 9$ nuclear fluorescent dye (Thermo Fisher Scientific, USA) for $30 \mathrm{~min}$. The stained biofilms were washed again with autoclaved water and mounted on a glass slide using mounting media (Thermo Fisher Scientific, USA). Confocal images were taken using Zeiss confocal laser scanning microscope (LSM 510). Argon Laser was excited at 450-490 nm, a 40× objective was used set at Zoom 2.

\section{Antibiotic susceptibility of ocular E. coli}

The susceptibility of the 12 clinical isolates of $E$. coli to different antibiotics as listed in Table 1 was determined on Mueller Hinton agar medium (MHA-Himedia) by Kirby Bauer disc diffusion method as per CLSI 2012 guidelines [31] to determine the susceptibility of the isolates to different antibiotics. In addition the minimum inhibitory concentration (MIC) of the antibiotic required to inhibit the growth of the 12 isolates was determined by the micro-dilution method. For this purpose, overnight grown culture from the BHI medium was adjusted to $0.5 \mathrm{McF}$ arland and $200 \mu \mathrm{l}$ was transferred into each well of the 96 well plate and incubated at $37^{\circ} \mathrm{C}$ for $16 \mathrm{~h}$ as described by The European Committee on Antimicrobial Susceptibility Testing (EUCAST) in 2003 [32] in the presence of the antibiotic. At the end of the incubation period OD $595 \mathrm{~nm}$ was determined. Each antimicrobial concentration was tested thrice and the mean values are presented. All the antibiotics were obtained from commercial sources. The susceptibility of $E$. coli isolate L-1216/2010 was also determined after the formation of the biofilm. In this experiment, overnight grown culture from then BHI medium was adjusted to $0.5 \mathrm{McFarland}$ and $200 \mu \mathrm{l}$ was transferred into each well of the 96 well plate and incubated at $37{ }^{\circ} \mathrm{C}$ for $48 \mathrm{~h}$ for biofilm formation. Planktonic cells were discarded, bound cells washed with milliQ water and then the antibiotic (dissolved in BHI medium) of a specific concentration was added to the biofilm and incubated for $16 \mathrm{~h}$. The capability of the 
Table 1 Resistance profile of 12 ocular E. coli to nine antibiotics by the Kirby-Bauer disc diffusion method and their biofilm forming potential by and the tissue culture plate (TCP) method

\begin{tabular}{|c|c|c|c|c|c|}
\hline S. no & E. coli strain & Ocular sample & Patient diagnosis & Resistance to antibiotics ( $\mu \mathrm{g} / \mathrm{disc})$ & $\begin{array}{l}\text { Biofilm production } \\
\text { by TCP method } \pm\end{array}$ \\
\hline 1 & L-1339/2013 & Conjunctival swab & Conjunctivitis & $\mathrm{Ce}, \mathrm{Cef}, \mathrm{Ci}, \mathrm{Ga}, \mathrm{Ge}, \mathrm{Mo}$, Of & - \\
\hline 2 & $L-1216 / 2010$ & Vitreous & Endophthalmitis & $\mathrm{Ci}$ & + \\
\hline 3 & L-2561/2013 & Vitreous & Endophthalmitis & None & + \\
\hline 4 & L-1920/2011 & Corneal scraping & Keratitis & Am, Ce, Cef, Ch, Ci, Ga, Ge, Mo, Of & + \\
\hline 5 & L-3781/2010 & Vitreous & Endophthalmitis & $\mathrm{Ce}$ & + \\
\hline 6 & L-3484/2010 & Vitreous & Endophthalmitis & None & - \\
\hline 7 & L-1573/2013 & Vitreous & Endophthalmitis & $\mathrm{Ci}, \mathrm{Mo}$, Of & + \\
\hline 8 & $L-494 / 2011$ & Vitreous & Endophthalmitis & $\mathrm{Am}, \mathrm{Ce}, \mathrm{Cef}, \mathrm{Ci}, \mathrm{Ga}, \mathrm{Ge}, \mathrm{Mo}$, Of & + \\
\hline 9 & $\mathrm{~L}-223 / 2014$ & Corneal scraping & Keratitis & $\mathrm{Ce}, \mathrm{Cef}, \mathrm{Ci}, \mathrm{Ga}, \mathrm{Mo}$, Of & + \\
\hline 10 & $L-304 / 2014$ & Corneal scraping & Keratitis & $\mathrm{Ce}, \mathrm{Cef}$ & + \\
\hline 11 & $L-811 / 2014$ & Lacrimal sac & Dacryocystitis & $\mathrm{Ce}, \mathrm{Cef}, \mathrm{Ci}, \mathrm{Ga}, \mathrm{Ge}, \mathrm{Mo}$, Of & + \\
\hline 12 & L-823/2014 & Corneal scraping & Keratitis & Cef & + \\
\hline
\end{tabular}

The antibiotics used are ( $\mu \mathrm{g} / \mathrm{disc})$ : Am amikacin (30), Ce ceftazidime (30), Cef cefuroxime (30), Ch chloramphenicol (30), Ci ciprofloxacin (5), Ga gatifloxacin (5), Ge gentamicin (10), Mo moxifloxacin (5) and Of ofloxacin (5)

+ , biofilm positive strains (black colonies); - , biofilm negative strains (red or pink colonies). biofilm positive strains (OD $>0.3$ at $595 \mathrm{~nm})$; - , biofilm negative strains $(\mathrm{OD}<0.3)$ at $595 \mathrm{~nm}$. The OD of the control wells was deducted in each case

bacterium to form biofilm was monitored in the absence and the presence of different antibiotics at different concentrations by the crystal violet method. The concentration of the antibiotic that inhibited the formation of the biofilm was determined. E. coli isolate L-1216/2010 in the planktonic phase (where in antibiotics were added after $24 \mathrm{~h}$ of growth) and non-biofilm forming $E$. coli (L-1339/2013) were used as controls for this experiment.

\section{DNA microarray analysis}

RNA was extracted from biofilm cells and non-biofilm cells incubated for $72 \mathrm{~h}$ at $37^{\circ} \mathrm{C}$ in BHI broth. For biofilm cells, E. coli (L-1216/2010) cells were allowed to grow and attach to plastic petri plates for $72 \mathrm{~h}(100 \mathrm{~mm}$ diameter containing $15 \mathrm{ml}$ medium). After $72 \mathrm{~h}$ the planktonic cells were removed and only cells that were attached to the petri plate were considered as the biofilm cells and scrapped from the petriplate and were collected in a Falcon tube. The non-biofilm E. coli L-1339/2013 was used as the control. Cells of $E$. coli L-1339/2013 were allowed to grow for $72 \mathrm{~h}$, centrifuged at 10,000 rpm in a microcentifuge (Eppendorf, New York, USA) and the pellet was collected. The pellets of the biofilm cells and non-biofilm cells were suspended separately in $1 \mathrm{ml}$ of ice cold phosphate buffer (pH 7.2) to which $3 \mathrm{ml}$ of RNAlater ${ }^{\circledR}$ (Invitrogen BioServices India Pvt. Ltd, Bangalore 560 066, India) was added and the suspensions incubated for 30 min. Collection of cells to the addition of RNAlater ${ }^{\circledR}$ was completed within 15 min. Extraction of total RNA, cDNA synthesis and DNA microarray analysis of all the six samples was done as described in our previous paper
[33]. Briefly for this, the total RNA from the samples was extracted using Qiagen RNeasy mini-prep kit. This is followed by cDNA synthesis from the RNA $(6 \mu \mathrm{g})$ by reverse transcription process using the first strand cDNA synthesis kit (Invitrogen Bioservices India Pvt. Ltd., Bangalore). Then the cDNA was fragmented with DNAse 1 (Promega Corporation, Madison, USA) and then labelled with biotin at the $3^{\prime}$ end using the labelling reagent from Affymetrix (CA, USA) and Terminal transferase enzyme (Promega). E. coli Genome 2.0 gene chip arrays were used for the DNA microarray study (Affymetrix CA, USA). The chip contained the complete genome of four E. coli strains (viz., non-pathogenic E. coli K12 MG1655, uropathogenic E. coli strain CFT073 and enterohemorrhagic E. coli O157:H7 strains EDL 933 and Sakai). The gene chip consists of approximately 10,000 probe sets for the 20,366 genes of all the four strains of E. coli. Three biological replicates were used for each condition of the experiment. The fragmented and labeled cDNA of E. coli cells from each biological replicate were processed independently and hybridized with DNA microarray chip. Thus for each condition of the experiment three DNA microarray chips were used. Microarray chips were then scanned using Affymetrix 428 Array Scanner and GCOS software to obtain images of the chips and further processed to get the florescent intensity of the probe sets. The fluorescent intensities were generated for the hybridized probes for each of the DNA microarray chips separately and analysed. The fluorescent intensity images were then normalized for background correction and data was analyzed using Gene Spring 12.5 software. To 
identify the significantly differentially regulated genes we have normalized the data of all biological replicates of both biofilm and non-biofilm E. coli cells by using PLIER (probe logarithmic intensity error estimation) followed by statistical analysis such as unpaired $T$ test and $P$ value calculation. Genes that exhibited $\geq 2.0$-fold increase or decrease (biofilm cells versus non-biofilm cells) in expression and $\mathrm{P} \leq 0.05$ were considered as significantly differentially regulated genes. The microarray data was submitted to Gene Expression Omnibus (GEO) web deposit of National Centre for Biotechnology Information (NCBI, Maryland, USA) with an accession number GSE77872.

\section{Annotation of the genes}

The differentially regulated genes were classified based on their function using Clusters of Orthologous Groups (COG), a software annotation pipeline associated with the Prokaryotic Genome Analysis Tool (PGAT) [34]. The COG protein database was generated by comparing predicted and known proteins in all completely sequenced microbial genomes to infer sets of orthologs. Various sets of differentially expressed genes based on their functionality were analysed for their interactions using GeneMANIA cytoscape plugin network analysis web tool [35]. Using GeneMANIA we performed all the possible default network interactions available for $E$. coli viz., co-expression, genetic interactions, protein interactions and other interactions. When the gene list exceeded more than 100 Cytoscape plugin was employed to derive the networks.

\section{Validation of microarray data by real time PCR (RT-PCR)}

Expression of the genes $y d c \mathrm{~T}, E C S 1633, y j c \mathrm{Q}$, ompC, $p e r \mathrm{M}, w a a \mathrm{~L}, f o c \mathrm{~A}, f l i \mathrm{C}$ and $o p r \mathrm{R}$ was validated by $\mathrm{RT}$ PCR following the protocol described in our previous paper [33]. The RT-PCR reactions were performed in triplicate. Relative expression of genes was calculated by $\Delta \Delta \mathrm{C}_{\mathrm{T}}$ method. Expression of $16 \mathrm{~S}$ rRNA gene was used as an internal standard. All values reported represent the mean of three independent experiments.

\section{Results}

\section{Ocular isolates of $E$. coli and antibiotic susceptibility}

Twelve E. coli isolates used in this study were isolated from keratitis (corneal scrapings), conjunctivitis (conjunctival swabs), endophthalmitis (vitreous fluid) or dacryocystitis (lacrimal sac pus) patients visiting the L. V. Prasad Eye Institute (LVPEI), Hyderabad, India, between the year 2010 and 2014 (Table 1; Additional file 1: Table S1). The demographic profile of the patients along with some clinical details is shown in the Additional file 1: Table S1. The patients were diagnosed and treated as per the institutional protocol. Visual acuity at presentation and at last follow up is also given in the Additional file 1: Table S1.

The antibiotic susceptibility results of the 12 ocular $E$. coli isolates (Table 1) indicated that except two isolates (L-3484/2010 and L-2561/2013) from the vitreous which were susceptible to all the antibiotics tested the remaining ten isolates were resistant to at least one or more antibiotics. Isolate (L-1920/2011) from corneal scrapings was the only isolate that showed resistance to all the antibiotics.

\section{Biofilm potential of ocular isolates of $E$. coli}

In the microtiter/tissue culture plate (TCP) method ten isolates were positive for biofilm formation and showed an $\mathrm{OD}>0.3$ at $595 \mathrm{~nm}$ compared to the negative strains whose OD was consistently $<0.3$ at $595 \mathrm{~nm}$ (Table 1; Additional file 2: Figure S1). The best biofilm forming isolate L-1216/2010 by the TCP method had an OD of 3.4 after $72 \mathrm{~h}$ of growth. The optimum conditions for biofilm formation as determined by the TCP method for all the isolates was $37^{\circ} \mathrm{C}$ at $\mathrm{pH} 7.3$ when grown on BHI or TSB medium and incubated for $72 \mathrm{~h}$. Growth and biofilm formation in E. coli strains was repeated three times under optimum conditions. All future experiments related to antibiotic susceptibility of the biofilm and the genes that are differentially regulated were done with L-1216/2010 which formed a biofilm and L-1339/2013 which did not form a biofilm as the control under the above optimum conditions.

Biofilm of ocular E. coli $\mathrm{L}-1216 / 2010$ was also visualised by scanning electron microscopy (HITACHI-Model S-3400 N, Japan) (Fig. 1a-c). The scanning electronic microscopic images revealed that at $24 \mathrm{~h}$ cells were attached to the substratum and were evenly spread and the morphology of the cells was discernible. By $48 \mathrm{~h}$ the cells were entangled in the EPS and by $72 \mathrm{~h}$ a luxuriant biofilm was formed and the cells were totally covered within the biofilm and individual cells were not clearly visible. Biofilm formation in ocular E. coli L-1216/2010 was also confirmed by using a Zeiss confocal laser scanning microscope. The results clearly indicated an increase in the thickness of the biofilm with growth. The biofilm increased in thickness from $5.30 \mu \mathrm{m}$ after $24 \mathrm{~h}$ to $15.01 \mu \mathrm{m}$ at $72 \mathrm{~h}$ of growth (Fig. $1 \mathrm{~d}-\mathrm{f}$ ).

The antibiotic susceptibility of biofilm of ocular E. coli L-1216/2010 was determined after allowing the cells to form a biofilm for $48 \mathrm{~h}$. Three biological replicates of ocular E. coli L-1216/2010 were used for this process. The results indicated that $E$. coli $\mathrm{L}-1216 / 2010$ in the biofilm phase required $>5 \mathrm{mg} / \mathrm{ml}$ antibiotic to exhibit total susceptibility to the tested antibiotics where as planktonic cells of E. coli 1216/2010 (Fig. 1h) and E. coli L-1339/2013 (Fig. 1i) and the remaining ten strains of ocular E. coli 

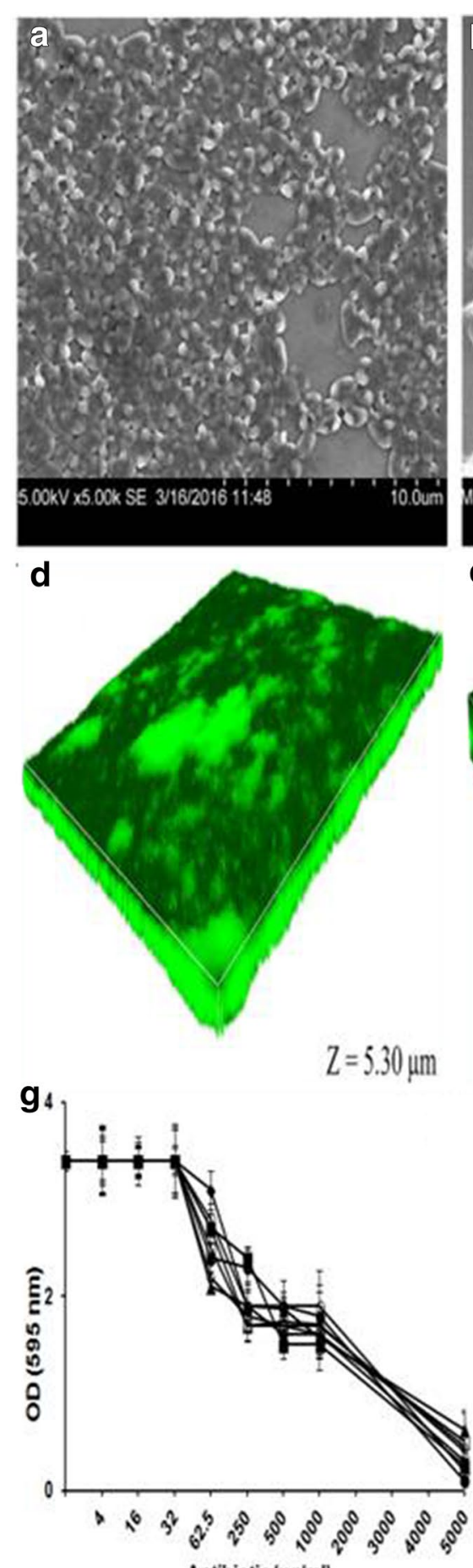
Antibiotic ( $\mu \mathrm{g} / \mathrm{ml})$

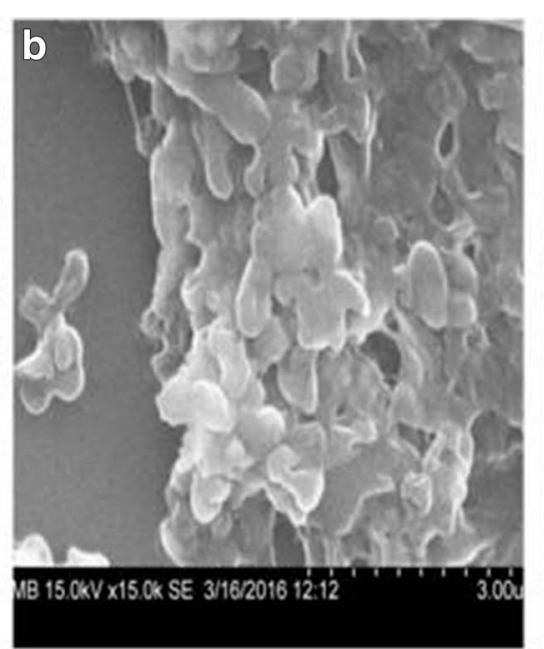

e
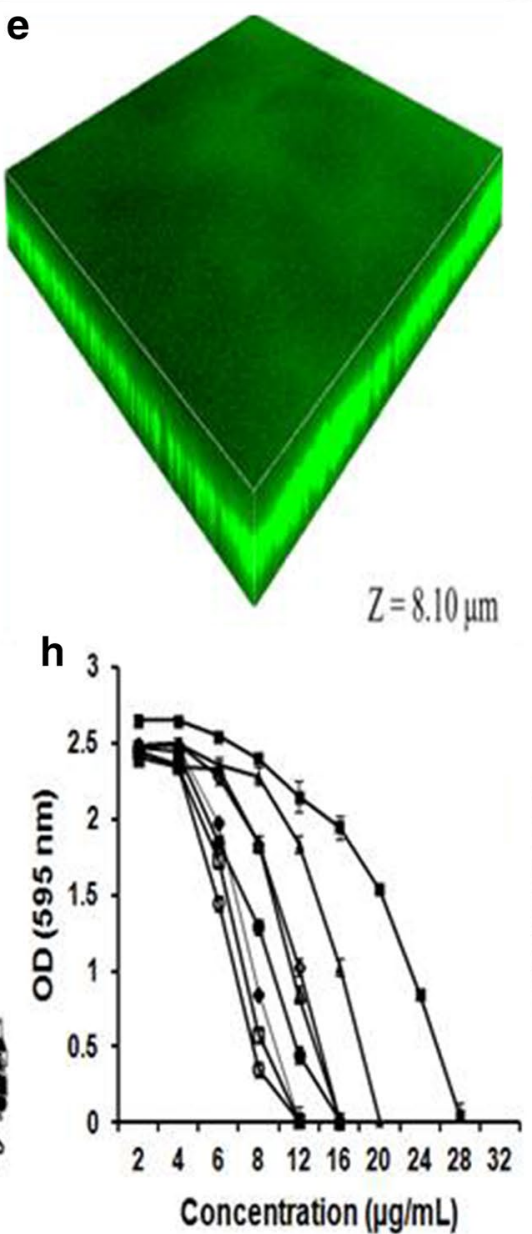

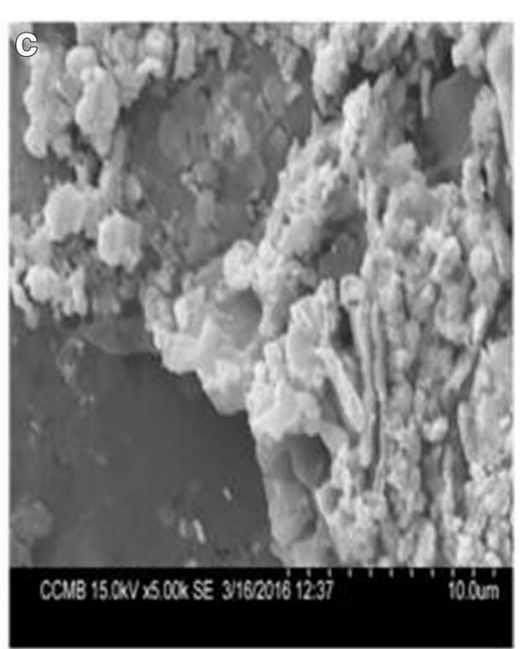

f

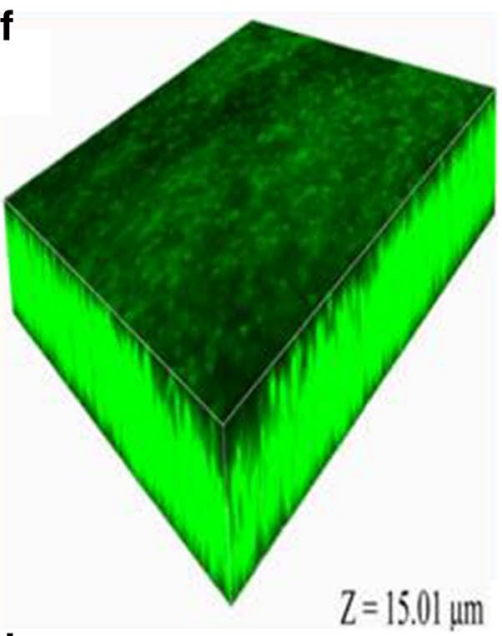

i 3

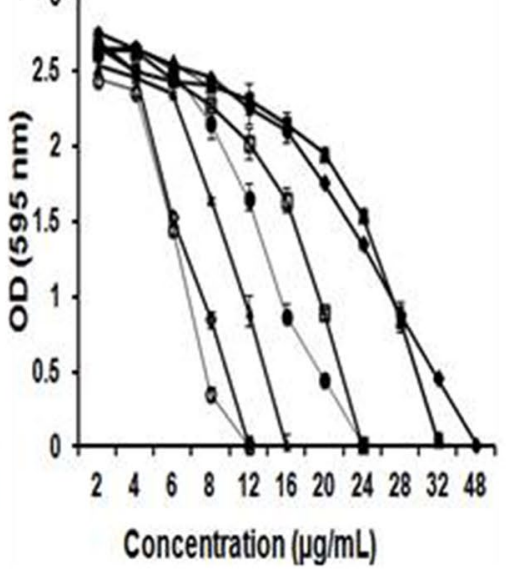

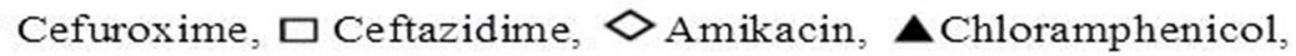

Cefotoxime, $\triangle$ Gentamicin, O Ciproflaxin,

Streptomycin 
(See figure on previous page.)

Fig. 1 Biofilm forming potential in ocular E. coli L-1216/2010 as monitored by scanning electron microscopy after 24 (a), 48 (b) and 72 (c) h of biofilm growth and by confocal scanning laser microscopy after 24 (d), 48 (e) and $72(\mathbf{f}) \mathrm{h}$ of biofilm growth. In $\mathbf{d}-\mathbf{f}$, the biofilm was stained with Syto9. The $Z$ axis indicates the thickness of the biofilm which is 5.30, 8.10 and $15.01 \mu \mathrm{m}$ after 24,48 and $72 \mathrm{~h}$ of biofilm growth. $\mathbf{g}$ Represents the susceptibility of ocular E. coli L-1216/2010 in the biofilm phase, $\mathbf{h}$ represents the susceptibility of ocular E. coli L-1216/2010 in the planktonic phase and $\mathbf{i}$ represents the susceptibility of non-biofilm forming E. coli L-1339/2013 to different concentrations of antibiotics

were less tolerant and exhibited no growth at concentrations ranging from 0.005 to $>0.064 \mathrm{mg} / \mathrm{ml}$ depending on the antibiotic tested (Fig. 1g-i; Table 2).

\section{Expression of genes in E. coli biofilm forming cells}

Analysis of the microarray data indicated that in the biofilm forming ocular E. coli (L-1216/2010) cells after $72 \mathrm{~h}$ of biofilm formation, hundreds of genes were significantly differentially expressed with a fold change $>2(\mathrm{P}<0.05)$ compared to the non biofilm cells of $E$. coli $\mathrm{L}-1339 / 2013$ (Fig. 2a). It was noted that 1292 (426 up and 866 down regulated) genes were significantly differentially regulated in the biofilm forming E. coli (L-1216/2010) cells compared to the non-biofilm forming E. coli L-1339/2013 cells. The cluster analysis (Fig. 2b) and heat maps (Fig. 2c) of the microarray data generated using mRNA of three biological replicates of biofilm cells of $E$. coli L-1339/2013 (BF1, BF2, BF3) and non biofilm forming cells from three biological replicates of $E$. coli L-1339/2013 (N1, N2, N3) also clearly showed that the biofilm cells were different from the non-biofilm cells (Fig. 2b, c). The Principal Component analysis also confirmed that the biofilm cells are more closely related and are less related to the nonbiofilm cells (Fig. 2d).

\section{Functional annotation of differentially expressed genes in E. coli biofilm forming cells}

Functional annotations and cluster categorization of the genes was done using DAVID, KEGG and COG analysis $[33,34]$. Genes that could not be annotated and the duplicate genes were removed from the differentially expressed gene list of microarray data. This resulted in differential expression of a total of 1060 (385 upregulated and 675 downregulated) genes (Additional file 3: Table S2, Additional file 4: Table S3). Using COG all the genes could be categorized into four main categories viz., cellular processes and signaling, information storage and processing, metabolism and poorly characterized or unknown genes (Table 3). Each category included a number of sub-categories and the differentially regulated genes (up and down regulated) were compared at the sub-category level with data obtained in this study and three earlier studies (Table 3).

Table 2 Minimum inhibitory concentrations of antibiotics against 12 ocular E. coli isolates

\begin{tabular}{|c|c|c|c|c|c|c|c|c|c|}
\hline \multirow[t]{2}{*}{ E. coli strain } & \multirow[t]{2}{*}{ Sample } & Amikacin & Ceftazidime & Cefuroxime & $\begin{array}{l}\text { Chloram- } \\
\text { phenicol }\end{array}$ & Ciprofloxacin & Gentamicin & Streptomycin & Cefotaxime \\
\hline & & \multicolumn{8}{|c|}{ Antibiotics MIC ( $\mu \mathrm{g} / \mathrm{ml})$} \\
\hline L-1339/2013 & $\begin{array}{l}\text { Conjunctival } \\
\text { swab }\end{array}$ & 12 & 24 & 48 & 16 & 12 & 32 & 24 & 32 \\
\hline L-1216/2013 & Vitreous & 16 & 12 & 28 & 20 & 12 & 12 & 16 & 16 \\
\hline L-2561/2013 & Vitreous & 6 & 2 & 4 & 4 & 0.5 & 2 & 12 & 1 \\
\hline L-1920/2011 & $\begin{array}{l}\text { Corneal scrap- } \\
\text { ing }\end{array}$ & 64 & 16 & 32 & 32 & 12 & 16 & 8 & 12 \\
\hline L-3781/2010 & Vitreous & 12 & 16 & 8 & 6 & 0.5 & 2 & 16 & 16 \\
\hline L-3484/2010 & Vitreous & 12 & 2 & 4 & 6 & 1 & 2 & 8 & 2 \\
\hline L-1573/2010 & Vitreous & 6 & 4 & 8 & 4 & 4 & 4 & 8 & 1 \\
\hline L-494/2011 & Vitreous & 64 & 16 & 32 & 6 & 8 & 16 & 12 & 12 \\
\hline L-223/2014 & $\begin{array}{l}\text { Corneal scrap- } \\
\text { ing }\end{array}$ & 12 & 24 & 48 & 8 & 4 & 4 & 16 & 32 \\
\hline L-304/2014 & $\begin{array}{l}\text { Corneal scrap- } \\
\text { ing }\end{array}$ & 6 & 24 & 32 & 6 & 0.5 & 2 & 8 & 1 \\
\hline L-811/2014 & Lacrimal sac & 6 & 16 & 32 & 4 & 4 & 32 & 12 & 32 \\
\hline L-823/2014 & $\begin{array}{l}\text { Corneal scrap- } \\
\text { ing }\end{array}$ & 6 & 2 & 24 & 2 & 0.5 & 4 & 6 & 1 \\
\hline
\end{tabular}



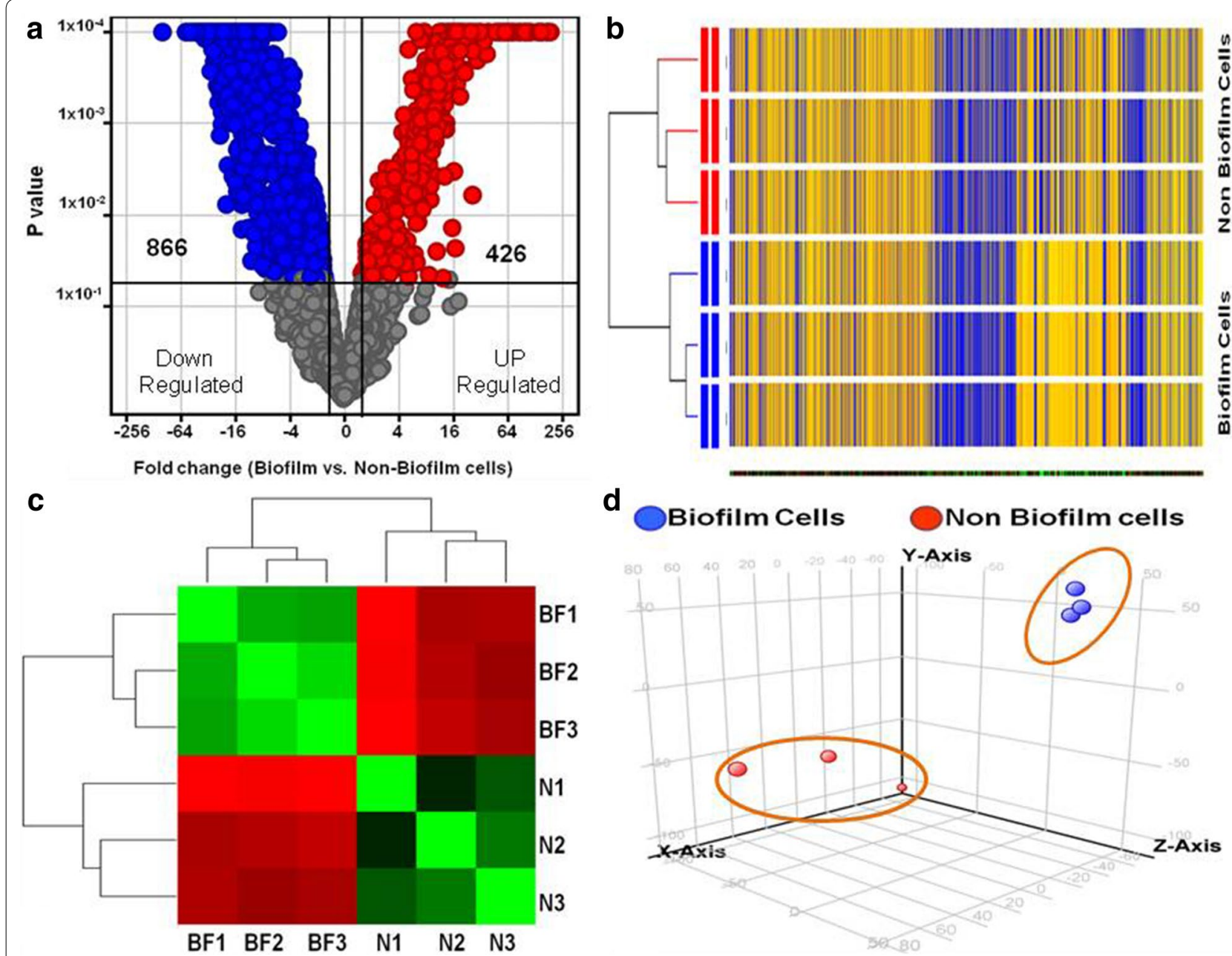

Fig. 2 Differential gene expression in $\mathrm{f}$. coli (L-1216/2010) with potential to form biofilm versus non-biofilm forming cells of E. coli (L-1339/2013) grown for $72 \mathrm{~h}$. In $\mathbf{a}$, in the volcano plots genes that are represented on the right side of the volcano-axis are up regulated and those that are on left side of the axis are down regulated. In b, cluster analysis of biofilm forming E. coli (L-1216/2010) with non-biofilm forming cells of E. coli (L-1339/2013). In c, heat map analysis shows that the biofilm cells (BF1-BF3) are less related to non-biofilm cells (N1-N3) of E. coli. Principal component analysis (d)

\section{Validation of DNA microarray results}

Expression of few of the genes that were differentially regulated in the sessile biofilm cells was validated by RTPCR. In accordance with DNA microarray results genes $y d c \mathrm{~T}$, ECS1633, yjcQ, ompC, perM and waaL showed increased expression $(\mathrm{P}<0.05)$ whereas genes focA, fliC and opr $\mathrm{R}$ showed decreased expression $(\mathrm{P}<0.05)$ in $E$. coli (L-1216/2010) with potential to form biofilm compared with E. coli (L-1339/2013) that does not form a biofilm (Fig. 3a, b).

\section{Genemania network analysis}

Following functional annotation and cluster categorization of the up regulated genes using DAVID, the up regulated genes in biofilm forming $E$. coli (L-1216/2010) cells were networked using GeneMANIA. GeneMANIA deduces networks by integrating publicly available genomic and proteomic data of 33 previous studies. GeneMANIA network analysis predicts that cell adhesion genes (fim $\mathrm{A}, \operatorname{yad} \mathrm{K}, \operatorname{yad} \mathrm{N}, \operatorname{yad} \mathrm{M}$ and $y a d \mathrm{C}$ ) were co-expressed along with genes encoding drug transport ( $m d t \mathrm{M}$ and $c y c \mathrm{~A})$, aldonate transport $(y j j \mathrm{~L})$, transporter activity $(h t r \mathrm{E})$, active transmembrane transporter activity (potG, mngA) and gluconate transport (gntP) (Fig. 4a). Network analysis also revealed that $e m r \mathrm{~B}$ interacts with proteins encoded by $m d t \mathrm{M}$ and $m d f \mathrm{~A}$ involved in multidrug resistance (Fig. 4a) thus accounting for the observed up regulation of $m d l \mathrm{~A}$ and $m d t \mathrm{M}$. Gene $e m r \mathrm{~B}$ also shared genetic interaction with several genes involved in aldonate and gluconate transport (Fig. 4a). Up regulated 
Table 3 Comparison of the differentially regulated genes in this study and three earlier studies based on COG sub-categories

\begin{tabular}{|c|c|c|c|c|c|c|c|c|}
\hline \multirow{3}{*}{$\begin{array}{l}\text { Functional group classification based on COG } \\
\text { E. coli strain } \\
\text { Regulation }\end{array}$} & \multirow{2}{*}{\multicolumn{2}{|c|}{$\frac{\text { Beloin et al. [40] }}{\text { E. coli K-12 }}$}} & \multirow{2}{*}{\multicolumn{2}{|c|}{$\begin{array}{l}\text { Domka et al. [42] } \\
\overline{\text { E. coli K-12 }}\end{array}$}} & \multirow{2}{*}{\multicolumn{2}{|c|}{$\begin{array}{l}\text { Hancock et al. } \\
{[43]} \\
\text { ABU E. coli }\end{array}$}} & \multirow{2}{*}{\multicolumn{2}{|c|}{$\begin{array}{l}\text { This study } \\
\text { Ocular E. coli }\end{array}$}} \\
\hline & & & & & & & & \\
\hline & Up & Down & Up & Down & Up & Down & Up & Down \\
\hline \multicolumn{9}{|l|}{ Cellular processes and signaling } \\
\hline M. Cell wall/membrane/envelope biogenesis & 19 & 9 & 9 & 8 & 4 & 25 & 14 & 14 \\
\hline D. Cell cycle control, mitosis and meiosis & 2 & 1 & 0 & 0 & 3 & 6 & 14 & 14 \\
\hline N. Cell motility & NA & NA & 32 & 1 & 1 & 0 & 7 & 19 \\
\hline O. Post-translational modification, protein turnover, and chaperones & 13 & 13 & 13 & 7 & 25 & 56 & 8 & 11 \\
\hline T. Signal transduction mechanisms & 5 & 0 & 11 & 3 & 12 & 2 & 7 & 5 \\
\hline U. Intracellular trafficking, secretion, and vesicular transport & NA & NA & 28 & 1 & 2 & 17 & 8 & 19 \\
\hline V. Defense mechanisms & NA & NA & 4 & 0 & 1 & 0 & 1 & 0 \\
\hline Sub-total & 39 & 23 & 97 & 20 & 48 & 106 & 59 & 82 \\
\hline \multicolumn{9}{|l|}{ Information storage and processing } \\
\hline A. Transcription, RNA processing and modification & 11 & 5 & 17 & 7 & 44 & 8 & 12 & 6 \\
\hline L. Replication, recombination and repair & 10 & 7 & 5 & 1 & 17 & 14 & 16 & 10 \\
\hline Sub-total & 21 & 12 & 22 & 8 & 61 & 22 & 28 & 16 \\
\hline \multicolumn{9}{|l|}{ Metabolism } \\
\hline C. Energy production and conversation & 23 & 9 & 23 & 16 & 12 & 34 & 12 & 18 \\
\hline E. Amino acid transport and metabolism & 9 & 22 & 20 & 15 & 5 & 36 & 20 & 17 \\
\hline F. Nucleotide transport and metabolism & 0 & 3 & 8 & 1 & 6 & 8 & 5 & 5 \\
\hline G. Carbohydrate transport and metabolism & 16 & 22 & 27 & 5 & 13 & 23 & 26 & 12 \\
\hline H. Coenzyme transport and metabolism & 3 & 5 & 6 & 1 & 9 & 14 & 5 & 7 \\
\hline I. Lipid transport and metabolism & 7 & 0 & 5 & 3 & 3 & 8 & 2 & 5 \\
\hline P. Inorganic ion transport and metabolism & 12 & 6 & 24 & 9 & 14 & 7 & 4 & 8 \\
\hline Q. Secondary metabolites biosynthesis, transport and catabolism & 2 & 1 & 5 & 0 & 2 & 7 & 5 & 2 \\
\hline Sub-total & 72 & 68 & 118 & 50 & 64 & 137 & 79 & 74 \\
\hline Unknown and general prediction only & 121 & 86 & 53 & 6 & 57 & 23 & 24 & 29 \\
\hline Total & 253 & 189 & 290 & 84 & 230 & 288 & 190 & 201 \\
\hline
\end{tabular}

The figures in each column indicate the number of genes up or down regulated in each category. Comparison between the four studies in terms of genes up or down regulated are not anticipated to be identical but the trends may be similar. For instance the number of genes up or down regulated when ABU E. coli is compared with ocular E. coli is similar for category V, L, F and I. Such comparisons could also be done between ocular E. coli and the other two strains of E. coli

genes in the biofilm forming cells belonging to lipopolysaccharide biosynthetic process (viz., waaJ, waaP, waaU and $w a a \mathrm{~B})$ were co-expressed in the network analysis (Fig. 4b). Network analysis also indicated that several of the genes integral to cell membrane (yii $, c b r \mathrm{~B}, c b r \mathrm{C}$, hisI) interact with one another (Additional file 5: Figure S2) and with genes encoding for putative fimbriae like proteins ( $y a d \mathrm{C}, y a d \mathrm{~L}$ and $y a d \mathrm{M}$ ), outer membrane proteins (htrE), transcriptional regulators (mngR, nha $\mathrm{R}$ ), DNAdamage repair proteins (uvrD), cytosine deaminase $(\operatorname{codA})$ and other genes. Network analysis also indicated that the hypothetical genes are interlinked to ABC transport protein genes, DNA replication, rrna genes and outer membrane genes and may thus be functionally useful for biofilm formation and virulence characteristic of the bacterium (Additional file 6: Figure S3).

\section{Discussion}

Our results indicate that 10 out of the 12 ocular E. coli isolates from conjunctival swab, corneal scrapings, vitreous fluid or lacrimal sac of patients were resistant to at least one or more of the nine antibiotics tested. Out of these ten antibiotic tolerant ocular E. coli, majority of the isolates $(8 / 10)$ were positive for biofilm formation by the TCP method thus implying a close association between antibiotic tolerance and biofilm formation [36, 37]. Surprisingly we also observed that $E$. coli L-2561/2013 from the vitreous fluid of Endophthalmitis patients was not resistant to any one of the antibiotics tested but possessed the ability to form biofilm. This is indeed interesting. A recent study also indicated that biofilm formation was independent of antibiotic resistance. For instance in Acinetobacter baumannii out 

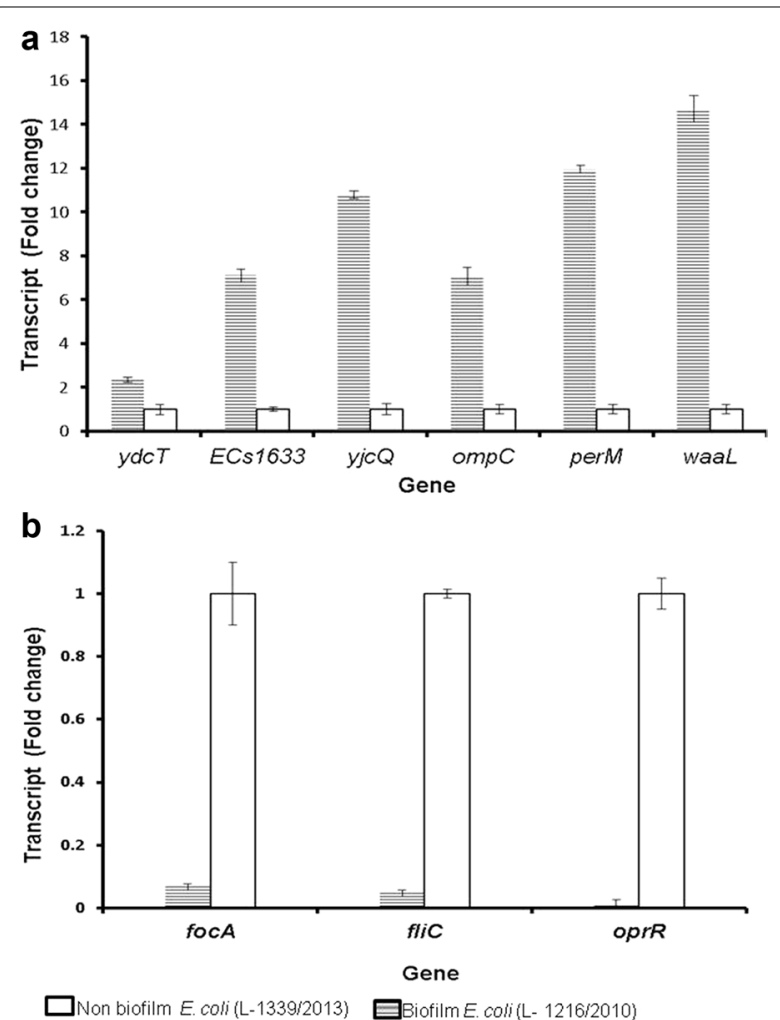

Fig. 3 Real-time PCR validation of the expression of genes in biofilm (closed box) and non-biofilm cells (hatched box) of E. coli (L-1216/2010) and E. coli (L-1339/2013) (open box) respectively. a Relative expression of up-regulated genes and $\mathbf{b}$ Relative expression of down-regulated gene

of 63 strong biofilm makers $79.4 \%$ were non-multidrugresistant strains and the authors observed a negative correlation between antibiotic resistance and biofilm forming capacity [38]. This observation was interpreted as indicating that biofilm improves the survival of bacteria in which resistance is low [38]. The study also indicated that ocular E. coli $\mathrm{L}-1216 / 2010$, required $>5 \mathrm{mg}$ antibiotic for total susceptibility in the biofilm phase compared to microgram quantities that were required to inhibit the growth in the planktonic phase thus implying 100-fold increase in resistance in the biofilm phase. These observations confirm an earlier study in Pseudomonas aeruginosa, E. coli, coagulase-negative Staphylococcus etc. which had also indicated increased resistance to antibiotics in biofilm phase versus planktonic phase. This is the first study on antibiotic susceptibility of an ocular isolate of $E$ coli in the biofilm phase to different antibiotics.

Differential gene expression in both pathogenic and non-pathogenic $E$. coli with the ability to form biofilm has been studied earlier (E. coli $\mathrm{K} 12$ and ABU E. coli) using various platforms and the results indicated that several genes were differentially regulated and the number varied from 233 to 815 genes representing about 5.4-19.07\% of the total genes [39-43]. The primary aim of this study was to identify genes that are differentially expressed during biofilm formation and also demonstrate that during biofilm formation the genes that facilitate drug resistance are up regulated. Therefore we chose L-1216/2010 to represent biofilm forming E. coli since it was the best biofilm forming isolate and resistant to just only one antibiotic and as a control we chose L-1399/2013 which was resistant to seven antibiotics and did not form a biofilm. This approach would allow us to identify genes which are up-regulated and associated with biofilm formation and also genes which are involved in drug resistance over and above the drug resistant $E$. coli L-1399/2013 which does not form a biofilm.

In the present study, we observed that in biofilm forming ocular E. coli L-1216/2010 the number of genes that were significantly differentially regulated during biofilm phase were higher (385 and 675 genes respectively were up and down regulated) compared to the previous studies. Comparison of the differentially regulated genes in ocular $E$. coli with that of $E$. coli $\mathrm{K} 12$ and $\mathrm{ABU}$ $E$. coli revealed that differential regulation of genes of the sub-category $U$ (intracellular trafficking, secretion, and vesicular transport), $\mathrm{V}$ (defence mechanisms) and $\mathrm{L}$ (Replication, recombination and repair) were similar in pathogenic ABU E. coli and ocular E. coli (Table 3). Further, ocular E. coli could be differentiated from E. coli $\mathrm{K} 12$, a laboratory strain, with respect to regulation of genes belonging to the sub-categories $\mathrm{D}$ (cell cycle control, mitosis and meiosis), $\mathrm{N}$ (cell motility), $\mathrm{U}$ (intracellular trafficking, secretion and vesicular transport) and $\mathrm{V}$ (defense mechanisms) (Table 3). In the subsequent part genes relevant to biofilm and virulence in antibiotic tolerant ocular E. coli L-1216/2010 would be discussed in comparison with the previously published data on nonpathogenic E. coli $\mathrm{K} 12$ and pathogenic ABU and uropathogenic E. coli.

\section{Genes involved in motility and adhesion}

In motile E. coli, biofilm formation is correlated with its ability to swim [44, 45]. Thus it is not surprising that genes coding for a second flagellar system fhiA [46], minor tail protein ECs1554, fimA coding for type $1 \mathrm{fim}$ briae [39-41], yadL and yadM [47], Z5029 and Z1651 coding for putative fimbrial-like adhesin proteins are up regulated in biofilm forming ocular E. coli L-1216/2010. Among these genes fhi A and ECs1554 are shown to be associated with biofilm formation in K-12 strains of E. coli $[48,49]$ and in one of the ABU strains VR50 [43]. But fim genes were not up regulated in expression in ABU strain 83972 [43] and in UPEC strain CFT073 [39]. 


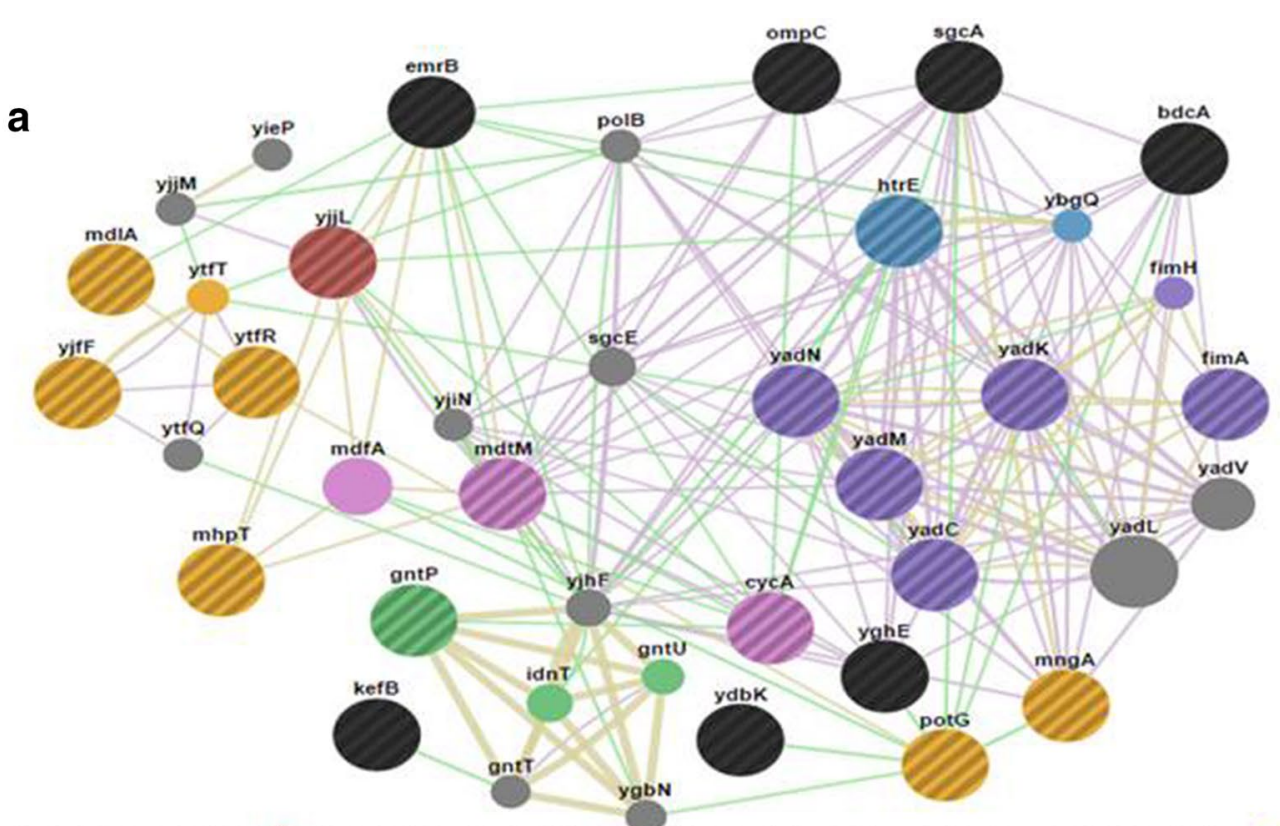

aldonate transport ( $)$, transporter activity $(0)$, active trans-membrane transporter activity $(0)$, cell adhesion $(\bullet)$, gluconate transport $(\bullet)$, drug transport $(\bullet)$

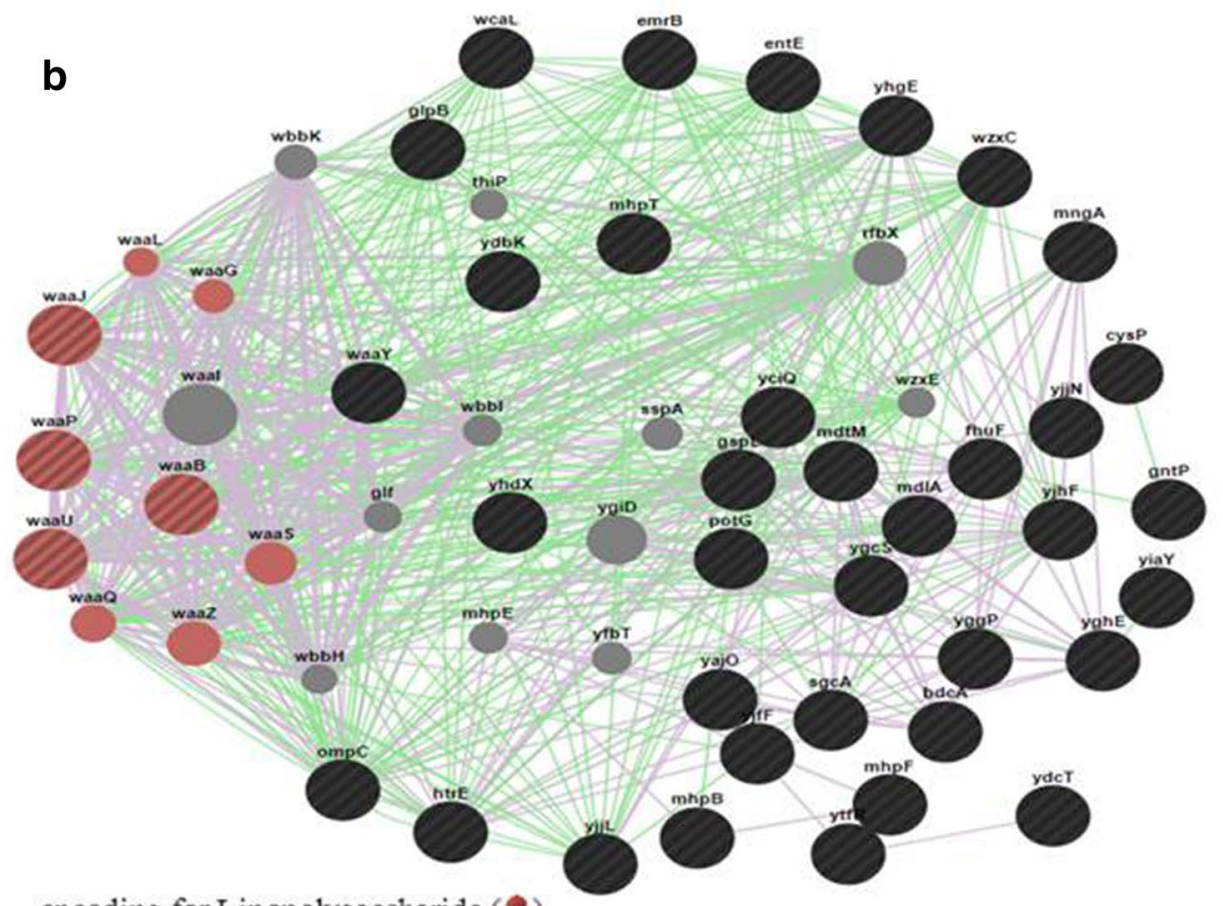

encoding for Lipopolysaccharide ( )

query genes (-), genes from the database (*), co-expression networks _ interactions _

Fig. 4 GeneMANIA network analysis of cell adhesion and transport genes. a Represents the interaction of genes at nodes encoding for transport activity with the cell adhesion genes. $\mathbf{b}$ Represents interaction of genes encoding for lipopolysaccharide 
Thus expression of genes encoding fimbriae and fimbriae related functions in E. coli appear to be strain-specific [50]. GeneMANIA network analysis also predicted a coexpression network interaction of fimA with that of fimbrial adhesion protein encoding genes $y a d \mathrm{~L}$ and $y a d \mathrm{M}$. Gene $b d c \mathrm{~A}$, a c-di-GMP-binding biofilm dispersal mediator protein was also up regulated in E. coli L-1216/2010 and co-expressed with genes encoding for cell adhesion (Fig. 4a). Several small molecules like Cyclic di-GMP (c-di-GMP) [51], acetyl phosphate (AcP) [52] and ppGpp promote biofilm formation. Biofilm formation in Gram negative bacterial cells is also facilitated by the adhesion of cells to the substratum which is conferred by the lipopolysaccharide (LPS) of the outer membrane [53]. In this study it is observed that genes coding for both the major components of LPS, namely hydrophobic lipid A moiety (waaB, waaP, waa and waaR) and the phosphorylated core oligosaccharide (waaU and waaY) and those coding for the $\mathrm{O}$ antigen synthesis (waa $\mathrm{L}$ and $w z z B$ ) are up regulated. However, in contrast in pathogenic ABU strains of $E$. coli, genes encoding lipid A remain unchanged and genes involved in peptidoglycan biosynthesis were down-regulated [43]. LPS, in E. coli also acts as a virulence factor [54].

\section{Genes involved in biofilm architecture}

Three exopolysaccharides, $\beta-1,6-N$-acetyl-D-glucosamine polymer (PGA) [55], colanic acid a negatively charged polymer of glucose, galactose, fucose and glucuronic acid and cellulose, have been detected in the biofilm matrix of $E$. coli and considered to be essential for normal biofilm architecture [56]. Concomitantly, in the present study $y h j \mathrm{~N}$ coding for cellulose synthase regulator protein was up regulated where as in ABU strains of $E$. coli genes involved in cellulose synthesis (bcsABZC and $b c s$ EFGgenes) were down regulated [43]. Genes encoding colanic acid synthesis (wca $\mathrm{L}$ and $w c a \mathrm{M})$ were down regulated in the ocular E. coli and ABU strains [43] probably because expression of colanic acid inhibits the biofilm ability of E. coli [57]. Further in ocular E. coli L-1216/2010 colicin protecting conserved protein encoding genes $c b r \mathrm{~B}$ and $c b r C$ are up regulated by 11 - and 288 -folds respectively compared to the non-biofilm forming cells.

\section{Genes involved in drug transport and active transport}

Genes encoding drug transport $(m d t \mathrm{M}$ and $c y c \mathrm{~A})$ and aldonate, active transport activity $(y j j \mathrm{~L}, h t r \mathrm{E}$, potGand mngA) (Fig. 4a) are differentially regulated in antibiotic tolerant ocular E. coli and may thus facilitate drug resistance [47]. In ocular E. coli in the biofilm phase gene emrB which confers resistance to cyanide $m$-chlorophenylhydrazone, tetrachlorosalicylanilide, organomercurials, nalidixic acid and thiolactomycin, genes $m d l \mathrm{~A}$ and $m d t \mathrm{M}$ which encode multidrug drug efflux pumps [58] and the sat gene encoding the secreted auto-transporter toxin (Sat) are up regulated. $c y c$ A that encodes for glycine, serine and alanine transport is predicted to genetically interact with gene $m d t \mathrm{M}$ and is 47 -fold down regulated in biofilm forming $E$. coli cells. cycA mutant strains of E. coli are known to exhibit significant resistance for D-cycloserine [59]. Thus down regulation of gene $c y c \mathrm{~A}$ in biofilm forming $E$. coli cells significantly contributes to antibiotic tolerance. Apart from these efflux pumps, $o m p C$ encoding secretion of extracellular proteins, gene $h t r E$ encoding putative chaperone-usher fimbrial protein [47] and many genes encoding dehydrogenases ( $m h p B$, $m h p F, y i a \mathrm{Y}, y a j \mathrm{O} / y d b \mathrm{~K}$ and $y j j \mathrm{~N}$ ) are up regulated. GeneMANIA network analysis of drug and active transport genes indicated that all these genes clustered through the genetic interaction networks and may facilitate drug resistance (Fig. 4a).

\section{Biofilm formation, virulence and other genes}

Genes involved in pathogenicity, biofilm formation, resistance to antimicrobial compounds and virulence are related. Accordingly complete or partial upregulation of 22 genes (c2418 to c2440) in the pathogenicity island PAI $\mathrm{IV}_{536}$ in the UPEC strain 536 and in ABU strains VR50 and strain 83972 [43] was observed during biofilm formation. In addition, $\mathrm{RfaH}$ a virulence regulator, which regulates expression of several virulent genes in $E$. coli is significantly up regulated in $A B U$ strains during biofilm phase [43]. None of the above genes was differentially regulated in ocular $E$. coli but up regulation of gene ECs3276 a virulence protein populating the cluster O80301 [60] was observed (Additional file 3: Table S2). Apart from this, upregulation of several genes encoding for toxin production and secretions (sat, $y j g \mathrm{~K}, \operatorname{chp} \mathrm{S}, \operatorname{chp} \mathrm{B}$ and $y g j \mathrm{~N}$ ) was observed in ocular $E$. coli biofilm cells which is an important factor that governs the virulence in pathogenic bacterial cells. Virulence of ocular E. coli may also be related to up regulation of Lipid A moiety of LPS, a potent stimulator of the immune system and a trigger of intense inflammation in the host cells [61]. Many genes encoding for proteins that influence antigen presentation $(w z z \mathrm{~B}$ and $w a a \mathrm{~L}$ ), extracellular matrix remodeling (yiiX), transport of aminoacids and other metabolites $(c b r \mathrm{~B}, c b r \mathrm{C}$, his $\mathrm{I}$ and $m g l \mathrm{~B}$ ) are also up regulated in ocular E. coli in biofilm stage and may have a role to play in virulence. Costa et al. [61] have recently suggested that in E. coli, during biofilm formation on abiotic surfaces, cells are exposed to several DNA damaging agents against which the cells need to be protected. In the present study gene ira $\mathrm{D}, u v r \mathrm{D}$ and $r e c \mathrm{C}$ involved in DNA damage repair are up regulated and could be acting to ensure survival 
of cells faced with oxidative damage. Thus the virulence presentation in ocular E. coli biofilm cells may be an exclusive process. It was also observed that ocular $E$. coli in biofilm phase show up regulation of stationary phase response genes $(s p e \mathrm{~B}, y b e \mathrm{~W}, h s c \mathrm{C}$ and $d j l \mathrm{C}$ which encode for Agmatinase) and genes indicative of anaerobic conditions $(d s m \mathrm{~B}, g l p \mathrm{~B}$ and $n r d \mathrm{D})$. However the stress response encoding genes up regulated in ABU strains of $E$. coli (such as $c s p \mathrm{G}, \operatorname{csp} \mathrm{H}, p p h \mathrm{~A}, i b p \mathrm{~A}$, $i b p$, soxS, hha and $y f \mathrm{D}$ ) were not up regulated in ocular $E$. coli except $u s p C$ encoding a universal stress protein which was up regulated [39-41, 43].

Several other genes involved in metabolism, biosynthesis, transport, efflux pumps, cell membrane structure, DNA replication etc. are also differentially regulated in ocular E. coli (Additional file 3: Table S2) and may thus be related to biofilm formation, virulence or both. Beloin et al. [45] in a review stated that E. coli species have not yet revealed all the secrets that contribute to bacterial biofilm research and one of the reasons is attributed to the fact that many of the differentially expressed genes were categorized either as unknown or coding for hypothetical proteins. In antibiotic resistant ocular $E$. coli also a substantial number of the genes are not annotated.

Virulence in $E$. coli is also known to be associated with extrachromosomal elements such as plasmids, associated bacteriophages and pathogenicity islands $[62,63]$ and a similar up-regulation was observed in ocular biofilm forming E. coli L-1216/2010 (Additional file 7: Table S4). In addition it was observed that other genes such as those conferring protection against colicin action $(c b r C)$ (Additional file 7: Table S4), ten toxin encoding prophage CP-933 related genes (as in Escherichia coli O157:H7 strain EDL933) [64], phage-related virulence protein encoding gene ins $\mathrm{Q}$, biofilm modulator toxin encoding gene yjgK (Additional file 3: Table S2, Additional file 4: Table S3) have also been observed to be up regulated Thus it appears that the differential regulation of extrachromosomal elements may be implicated in the biofilm formation and antibiotic resistance in ocular E. coli L-1216/2010.

\section{Conclusions}

We report the first global gene expression data of antibiotic resistant ocular biofilm forming E. coli cells and demonstrate that antibiotic tolerance of ocular biofilm forming E. coli L-1216/2010 is dependent on up regulation in expression of genes encoding drug transport, active transport, multi-drug efflux pumps and genes conferring tolerance to drugs. Simultaneously genes required for biofilm formation such as genes involved adhesion, LPS production and biofilm architecture are up regulated. This study also identifies hitherto unreported sets of oxidative stress protecting genes and extrachromosomal elements such as plasmids, associated bacteriophages and pathogenicity islands which are also up regulated during biofilm formation in ocular $E$. coli. It is envisaged that inhibition of the above up regulated genes by using inhibitors could serve as a strategy for preventing biofilm formation and overcoming drug resistance.

In subsequent studies we hope to validate a few of the genes for which functions have not been assigned by specific gene knock out studies by transposon mediated targeted mutagenesis as reported earlier by us [65-67]. Inhibition of up regulated genes either by using already known inhibitors or by designing new inhibitors would also be attempted as an alternative strategy.

\section{Additional files}

Additional file 1: Table S1. Clinical profile of the patients included in the study.

Additional file 2: Figure S1. Biofilm forming potential in twelve ocular isolates of $E$. coli from Vitreous, Corneal scraping, Conjunctival swab and Lacrimal gland evaluated by tissue culture plate method. The dark blue sediment adhering to the bottom of the well is indicative of biofilm forming potential of the isolates. isolates from left to right are $L-1339 / 2013$, L-1216/2010, L-2561/2013, L-1920/2011, L-3781/2010, L-3484/2010, L-1573/2013, L-494/2011, L-223/2014, L-304/2014, L-811/2014 and $L-823 / 2014$ respectively. Except isolates $L-1339 / 2013$ and $L-3484 / 2010$ all the remaining isolates are positive for biofilm forming potential.

Additional file 3: Table S2. Up regulation of significantly differentially regulated genes in ocular Escherichia coli L-1216/2010 biofilm cells versus ocular E. coli L-1339/2013 cells which do not form a biofilm as the control.

Additional file 4: Table S3. Down regulation of significantly differentially regulated genes in ocular Escherichia coli L-1216/2010 biofilm cells versus ocular E. coli L-1339/2013 cells which do not form a biofilm as the control.

Additional file 5: Figure S2. Network analysis co-expression showing interaction of genes encoding for integral cell membrane proteins (yiiX, $c b r \mathrm{~B}, c b r \mathrm{C}, c y c \mathrm{~A}$, his $\mathrm{L}$ and $\mathrm{mg} / \mathrm{B}$ ) between themselves and with genes encoding for putative fimbriae like proteins (yadC, yadK, yad L and yadM), outer membrane proteins ( $h t r E)$, transcriptional regulators ( $m n g R$, nhaR), DNA damage repair (uvrD), cytosine deaminase (codA) etc.

Additional file 6: Figure S3. Cytoscape network analysis showing interaction of genes encoding for hypothetical proteins.

Additional file 7: Table S4. Expression of up regulated extrachromosomal genes in ocular Escherichia coli L-1216/2013 compared to Escherichia coli K-12 substr. MG1655.

\section{Abbreviations}

VTEC: verotoxigenic; EHEC: entero-haemorrhagic; EIEC: entero-invasive; ExPEC: extra-intestinal pathogenic; UPEC: uro-pathogenic; TCP: tissue culture plate; BHI: brain-heart infusion; TSB: tryptic soy broth; SEM: scanning-electron microscopy; CLSM: confocal laser scanning microscope; MHA: Mueller-Hinton agar medium; MIC: minimum inhibitory concentration; CLSI: Clinical and Laboratory Standards Institute; EUCAST: European Committee on Antimicrobial Susceptibility; PLIER: probe logarithmic intensity error estimation; GEO: Gene Expression Omnibus; COG: Clusters of Orthologous Groups; DAVID: Database for Annotation, Visualization and Integrated Discovery; KEGG: Kyoto Encyclopedia of Genes and Genomes. 


\section{Authors' contributions}

KR did the biofilm assay, antibiotic resistance experiments and helped in mRNA and CDNA preparation and in data presentation. KA participated in mRNA extraction, cDNA preparation, DNA microarray experiment and data analysis and manuscript writing. GSR participated in DNA microarray experiment and provided logistic support. HKA supported microscopic imaging. SS characterized the E. coli strains and participated in data analysis, manuscript writing and editing. SSh conceived the project, executed the project and helped in manuscript writing and finalization. All authors read and approved the final manuscript.

\section{Author details}

1 Jhaveri Microbiology Centre, Brien Holden Eye Research Centre, L V Prasad Eye Institute, Kallam Anji Reddy campus, Hyderabad 500007, India. ${ }^{2}$ CSIRCentre for Cellular and Molecular Biology, Hyderabad, India. ${ }^{3}$ Research Scholar, Manipal University, Manipal, Karnataka 576104, India.

\section{Acknowledgements}

Our thanks to the Director Centre for Cellular and Molecular Biology and Director of Research Prof Brien Holden Eye Research Centre, L V Prasad Eye Institute, Hyderabad for funds and facilities.

\section{Competing interests}

The authors declare that they have no competing interests.

\section{Availability of data and materials}

The microarray data was submitted to Gene Expression Omnibus (GEO) web deposit of National Centre for Biotechnology Information (NCBI, Maryland, USA) with an accession number GSE77872.

\section{Ethics statement}

This study was carried out according to the institutional ethical committee guidelines at the LV Prasad Eye Institute, Hyderabad, India (ECR/468/Inst./ AP/2013).

\section{Funding}

We would also like to state that this project was not funded by any source.

\section{Publisher's Note}

Springer Nature remains neutral with regard to jurisdictional claims in published maps and institutional affiliations.

Received: 16 February 2017 Accepted: 25 March 2017

Published online: 03 April 2017

\section{References}

1. Conway T, Cohen PS. Commensal and pathogenic Escherichia coli metabolism in the gut. Microbiol Spectr. 2015;3(3):10.

2. Stenutz R, Weintraub A, Widmalm G. The structures of Escherichia coli O-polysaccharide antigens. FEMS Microbiol Rev. 2006;30(3):382-403.

3. Croxen MA, Law RJ, Scholz R, Keeney KM, Wlodarska M, Finlay BB. Recent advances in understanding enteric pathogenic Escherichia coli. Clin Microbiol Rev. 2013;26(4):822-80.

4. Kwon T, Kim W, Cho SH. Comparative genomic analysis of Shiga toxinproducing and non-Shiga toxin-producing Escherichia coli $\mathrm{O} 157$ isolated from outbreaks in Korea. Gut Pathogens. 2017;9:7.

5. Byappanahalli MN, Nevers MB, Korajkic A, Staleyc ZR, Harwood VJ. Enterococci in the environment. Microbiol Mol Biol Rev. 2012;76(4):685-706.

6. Sharma S. Diagnosis of infectious diseases of the eye. Eye. 2012;26(2):177-84.

7. Abelson MB, McLaughlin J. Of biomes, biofilm and the ocular surface. Rev Ophthalmol. 2012;19:52-4.

8. Bharathi MJ, Ramakrishnan R, Meenakshi R, Padmavathy S, Shivakumar C, Srinivasan M. Microbial keratitis in south india: influence of risk factors, climate, and geographical variation. Ophthalmic Epidemiol. 2007;14(2):61-9.
9. Ramage G, Mowat E, Jones B, William C. Our current understanding of fungal biofilms. Crit Rev Microbiol. 2009;35(4):340-55.

10. Sengupta J, Saha S, Khetan A, Sarkar SK, Mandal SM. Effects of lactoferricin B against keratitis-associated fungal biofilms. J Infect Chemother. 2012;18(5):698-703.

11. Graham JE, Moore JE, Jiru X, Moore JE, Goodall EA, Dooley JS, Hayes VE, Dartt DA, Downes CS, Moore TC. Ocular pathogen or commensal: a PCRbased study of surface bacterial flora in normal and dry eyes. Investig Ophthalmol Vis Sci. 2007:48(12):5616-23.

12. Dong Q, Brulc JM, lovieno A, Bates B, Garoutte A, Miller D, Revanna KV, Gao X, Antonopoulos DA, Slepak VZ, Shestopalov VI. Diversity of bacteria at healthy human conjunctiva. Investig Ophthalmol Vis Sci. 2011;52(8):5408-13.

13. Schabereiter-Gurtner C, Maca S, Rolleke S, Nigl K, Lukas J, Hirschl A, Lubitz W, Barisani-Asenbauer T. 16S rDNA-based identification of bacteria from conjunctival swabs by PCR and DGGE fingerprinting. Investig Ophthalmol Vis Sci. 2001;42(6):1164-71.

14. Lee $\mathrm{SH}, \mathrm{Oh} \mathrm{DH}$, Jung JY, Kim JC, Jeon CO. Comparative ocular microbial communities in humans with and without blepharitis. Investig Ophthalmol Vis Sci. 2012:53(9):5585-93.

15. Willcox MD. Characterization of the normal microbiota of the ocular surface. Exp Eye. 2013;117:99-105.

16. Sharma S, Kunimoto DY, Garg P, Rao GN. Trends in antibiotic resistance of corneal pathogens: part I. An analysis of commonly used ocular antibiotics. Indian J Ophthalmol. 1999;47(2):95-100.

17. Hoyle BD, Wong CK, Costerton JW. Disparate efficacy of tobramycin on $\mathrm{Ca}(2+)-, \mathrm{Mg}(2+)-$, and HEPES-treated Pseudomonas aeruginosa biofilms. Can J Microbiol. 1992;38(11):1214-8.

18. Elder MJ, Stapleton F, Evans E, Dart JK. Biofilm-related infections in ophthalmology. Eye. 1995;9(1):102-9.

19. Zegans ME, Becker HI, Budzik J, O'Toole G. The role of bacterial biofilms in ocular infections. DNA Cell Biol. 2002;21(5-6):415-20.

20. Heilmann C, Götz F. Cell-cell communication and biofilm formation in Gram-positive bacteria. In: Krämer R, Jung K, editors. Bacterial signaling. Wiley: Weinheim; 2010. p. 1-22.

21. Katiyar R, Vishwakarma A, Kaistha SD. Analysis of biofilm formation and antibiotic resistance of microbial isolates from intraocular lens following conventional extracapsular cataract surgery. Int J Res Pure Appl Microbiol. 2012;2(2):20-4

22. Sherwal BL, Verma AK. Epidemiology of ocular infection due to bacteria and fungus - a prospective study. JK Sci. 2008;10(3):127-31.

23. Gopinathan U, Sharma S, Garg P, Rao GN. Review of epidemiological features, microbiological diagnosis and treatment outcome of microbial keratitis: experience of over a decade. Indian J Ophthalmol. 2009;57(4):273-9

24. Callegan MC, Engelbert M, Parke DW, Jet BD, Gilmore MS. Bacterial endophthalmitis: epidemiology, therapeutics, and bacterium-host interactions. Clin Microbiol Rev. 2002;15(1):111-24.

25. Jindal A, Pathengay A, Mithal K, Jalali S, Mathai A, Pappuru RR, Narayanan R, Chhablani J, Motukupally SR, Sharma S, Das T, Flynn HW. Endophthalmitis after open globe injuries: changes in microbiological spectrum and isolate susceptibility patterns over 14 years. J Ophthalmic Inflamm Infect. 2014;4:5.

26. Murthy TA, Rangappa P, Rao S, Rao K. ESBL E. coli urosepsis resulting in endogenous panophthalmitis requiring evisceration of the eye in a diabetic patient. Case Rep Infect Dis. 2015;2015:4.

27. Stratton M, Capitena C, Christensen L, Paciuc-Beja M. Escherichia coli eyelid abscess in a patient with alcoholic cirrhosis. Case Rep Ophthalmol Med. 2015;2015:2.

28. Fux CA, Costerton JW, Stewart PS, Stoodley P. Survival strategies of infectious biofilms. Trends Microbiol. 2005;13(1):34-40.

29. López D, Vlamakis H, Kolter R. Biofilms. Cold Spring Harb Perspect Biol. 2010;2(7):a000398.

30. Ramli NSK, Eng Guan C, Nathan S, Vadivelu J. The effect of environmental conditions on biofilm formation of Burkholderia pseudomallei clinical isolates. PLoS ONE. 2012:7(9):e44104.

31. CLSI, Performance Standards for Antimicrobial Disk Susceptibility Tests. Approved standard, 7th ed. CLSI document M02-A11. Clinical and Laboratory Standards Institute, 950 West Valley Road, Suite 2500, Wayne, Pennsylvania 19087, USA. 2012 
32. EUCAST, European Committee for Antimicrobial Susceptibility Testing (EUCAST) of the European Society of Clinical Microbiology and Infectious Diseases (ESCMID). Determination of minimum inhibitory concentrations (MICs) of antibacterial agents by broth dilution. Clin Microbiol Infect. 2003;9:ix-xv.

33. Arunasri K, Adil M, VenuCharan K, Suvro C, Himabindu Reddy S, Shivaji S. Effect of simulated microgravity on E. coli K12 MG1655 growth and gene expression. PLOS ONE. 2013;8(3):e57860.

34. Brittnacher MJ, Fong C, Hayden HS, Jacobs MA, Radey M, Rohmer L. PGAT: a multi strain analysis resource for microbial genomes. Bioinformatics. 2011:27(17):2429-30.

35. Montojo J, Zuberi K, Rodriguez H, Kazi F, Wright G. GeneMANIA cytoscape plugin: fast gene function predictions on the desktop. Bioinformatics. 2010;26(22):2927-8

36. Mishra SK, Basukala P, Basukala O, Parajuli K, Pokhrel BM, Rijal BP. Detection of biofilm production and antibiotic resistance pattern in clinical isolates from indwelling medical devices. Curr Microbiol. 2015;70(1):128-34.

37. Jassim SH, Sivaraman KR, Jimenez JC, Jaboori AH, Federle MJ, de la Cruz J, Cortina MS. Bacteria colonizing the ocular surface in eyes with boston type 1 keratoprosthesis: analysis of biofilm-forming capability and vancomycin tolerance. Investig Ophthalmol Vis Sci. 2015;56(8):4689-96.

38. Qi L, Li H, Zhang C, Liang B, Li J, Wang L, Du X, Liu X, Qiu S, Song H. Relationship between antibiotic resistance, biofilm formation, and biofilm-specific resistance in Acinetobacter baumannii. Front Microbiol. 2016;7:483.

39. Schembri MA, Kjaergaard K, Klemm P. Global gene expression in Escherichia coli biofilms. Mol Microbiol. 2003;48(1):253-67.

40. Beloin C, Valle J, Latour-Lambert P, Faure P, Kzreminski M, Balestrino D, Haagensen JA, Molin S, Prensier G, Arbeille B, Ghigo JM. Global impact of mature biofilm lifestyle on Escherichia coli K-12 gene expression. Mol Microbiol. 2004;51(3):659-74.

41. Ren D, Bedzyk LA, Thomas SM, Ye RW, Wood TK. Gene expression in Escherichia coli biofilms. Appl Microbiol Biotechnol. 2004:64(4):515-24.

42. Domka J, Lee J, Wood TK. YliH (BssR) and YceP (BssS) regulate Escherichia coli K-12 biofilm formation by influencing cell signaling. Appl Environ Microbiol. 2006;72(4):2449-59.

43. Hancock V, Klemm P. Global gene expression profiling of asymptomatic bacteriuria Escherichia coli during biofilm growth in human urine. Infect Immun. 2007;75(2):966-76.

44. Wood TK, Gonzalez Barrios AF, Herzberg M, Lee J. Motility influences biofilm architecture in Escherichia coli. Appl Microbiol Biotechnol. 2006;72(2):361-7.

45. Beloin C, Roux A, Ghigo JM. Escherichia coli biofilms. Curr Top Microbiol Immunol. 2008:322:249-89.

46. Korea CG, Badouraly R, Prevost MC, Ghigo JM, Beloin C. Escherichia coli K-12 possesses multiple cryptic but functional chaperone-usher fimbriae with distinct surface specificities. Environ Microbiol. 2010;12(7):1957-77.

47. Reisner A, Haagensen JA, Schembri MA, Zechner EL, Molin S. Development and maturation of Escherichia coli K-12 biofilms. Mol Microbiol. 2003;48(4):933-46.

48. Ren CP, Beatson SA, Parkhill J, Pallen MJ. The flag-2 locus, an ancestral gene cluster, is potentially associated with a novel flagellar system from Escherichia coli. J Bacteriol. 2005;187(4):1430-40.

49. Prigent-Combaret C, Prensier G, Le Thi TT, Vidal O, Lejeune P, Dorel C. Developmental pathway for biofilm formation in curli-producing Escherichia coli strains: role of flagella, curli and colanic acid. Environ Microbiol. 2000;2(4):450-64.

50. Van der Woude MW. Re-examining the role and random nature of phase variation. FEMS Microbiol Lett. 2006;254(2):190-7.

51. Simm R, Morr M, Kader A, Nimtz M, Romling U. GGDEF, EAL domains inversely regulate cyclic di-GMP levels and transition from sessility to motility. Mol Microbiol. 2004;53(4):1123-34.
52. Wolfe AJ, Chang DE, Walker JD, Seitz-Partridge JE, Vidaurri MD, Lange CF, Prüss BM, Henk MC, Larkin JC, Conway T. Evidence that acetyl phosphate functions as a global signal during biofilm development. Mol Microbiol. 2003;48(4):977-88.

53. Whitfield C. Biosynthesis and assembly of capsular polysaccharides in Escherichia coli. Annu Rev Biochem. 2006;75:39-68.

54. Hanna A, Berg M, Stout V, Razatos A. Role of capsular colanic acid in adhesion of uropathogenic Escherichia coli. Appl Environ Microbiol. 2003;69(8):4474-81.

55. Schembri MA, Dalsgaard D, Klemm P. Capsule shields the function of short bacterial adhesins. J Bacteriol. 2004;186(5):1249-57.

56. Paul N, Danese LA, Kolter PA. Exopolysaccharide production is required for development of Escherichia coli K-12 biofilm architecture. J bacteriol. 2000;182(12):3593-6.

57. Costa SB, Campos AC, Pereira AC, de Mattos-Guaraldi AL, Junior RH, Rosa AC, Asad LM. Adherence to abiotic surface induces SOS response in Escherichia coli K-12 strains under aerobic and anaerobic conditions. Microbiology. 2014;160(9):1964-73.

58. Donlan RM. Biofilms: microbial life on surfaces. Emerg Infect Dis. 2002:8(9):881-90.

59. Chalabaev S, Chauhan A, Novikov A, Iyer P, Szczesny M, Beloin C, Caroff $\mathrm{M}$, Ghigo J-M. Biofilms formed by Gram-negative bacteria undergo increased lipid a palmitoylation, enhancing in vivo survival. mBio. 2014;5(4):e01116-14.

60. Baisa G, Stabo NJ, Welch RA. Characterization of Escherichia coli D-cycloserine transport and resistant mutants. J Bacteriol. 2013;195(7):1389-99.

61. Bolstad HM, Botelho DJ, Wood MJ. Proteomic analysis of protein-protein interactions within the CSD Fe-S cluster biogenesis system. J Proteome Res. 2010;9(10):5358-69.

62. Coler RN, Bertholet S, Moutaftsi M, Guderian JA, Windish HP, Baldwin SL, Laughlin EM, Duthie MS, Fox CB, Carter D, Friede M, Vedvick TS, Reed SG. Development and characterization of synthetic glucopyranosyl lipid adjuvant system as a vaccine adjuvant. PLoS ONE. 2011;6(1):e0016333.

63. Johnson TJ, Nolan LK. Pathogenomics of the virulence plasmids of Escherichia coli. Microbiol Mol Biol Rev. 2009;73(4):750-74.

64. Dobrindt U, Agerer F, Michaelis K, Janka A, Buchrieser C, Samuelson M, Svanborg C, Gottschalk G, Karch H, Hacker J. Analysis of genome plasticity in pathogenic and commensal Escherichia coli isolates by use of DNA arrays. J Bacteriol. 2003;185(6):1831-40.

65. Herold S, Siebert J, Huber A, Schmidt H. Global expression of prophage genes in Escherichia coli O157:H7 strain EDL933 in response to norfloxacin. Antimicrob Agents Chemother. 2005:49(3):931-44.

66. Singh AK, Pindi PK, Dube S, Sundareswaran VR, Shivaji S. Importance of trmE for growth of the psychrophile Pseudomonas syringae at low temperatures. Appl Environ Microbiol. 2009;75(13):4419-26.

67. Sundareswaran VR, Singh AK, Dube S, Shivaji S. Aspartate aminotransferase is involved in cold adaptation in psychrophilic Pseudomonas syringae. Arch Microbiol. 2010;192(8):663-72.

\section{Submit your next manuscript to BioMed Central and we will help you at every step:}

- We accept pre-submission inquiries

- Our selector tool helps you to find the most relevant journal

- We provide round the clock customer support

- Convenient online submission

- Thorough peer review

- Inclusion in PubMed and all major indexing services

- Maximum visibility for your research

Submit your manuscript at www.biomedcentral.com/submit 